\title{
Detrital zircon of 4.1 Ga in South China
}

\author{
XU YaJun ${ }^{1,2}$, DU YuanSheng ${ }^{1,2 *}$, HUANG HongWei ${ }^{3}$, HUANG ZhiQiang $^{3}$, HU LiSha $^{1}$, \\ ZHU YanHui ${ }^{1} \&$ YU WenChao ${ }^{1}$

\footnotetext{
${ }^{1}$ State Key Laboratory of Biogeology and Environmental Geology, China University of Geosciences, Wuhan 430074, China;

${ }^{2}$ State Key Laboratory of Geological Processes and Mineral Resources, China University of Geosciences, Wuhan 430074, China;

${ }^{3}$ Guangxi Bureau of Geology, Mineral Prospecting and Exploitation, Nanning 530023, China
}

Received June 26, 2012; accepted August 15, 2012; published online September 25, 2012

\begin{abstract}
One hadean zircon from the Cambrian sandstone in the southern part of South China has a U-Pb age of $4107 \pm 29 \mathrm{Ma}$ with $\varepsilon_{\mathrm{Hf}}(t)$ value similar to that of the homochronous depleted mantle and $\mathrm{Hf}$ model age of $4102 \pm 21 \mathrm{Ma}$. This demonstrates the existence of hadean crustal remnant in South China. A close match between the U-Pb age and Hf model age with the highly position $\varepsilon_{\mathrm{Hf}}(t)$ value indicates the growth and immediate reworking of juvenile crust from the depleted mantle at ca $4.1 \mathrm{Ga}$. The prominent "Pan-African" and Grenville zircons derived from the exotic sources were also found in the sample, which indicates a linking between South China and Gondwana in the Cambrian period. The southern part of South China has complex histories of crustal growth and tectonic evolution.
\end{abstract}

detrital zircon, 4.1 Ga, Cambrian, South China

Citation: $\quad$ Xu Y J, Du Y S, Huang H W, et al. Detrital zircon of 4.1 Ga in South China. Chin Sci Bull, 2012, 57: 4356-4362, doi: 10.1007/s11434-012-5465-8

The formation and evolution of early crust are of great significance to the process and mechanism of continental generation. U-Pb age of zircon combined with its $\mathrm{Hf}$ isotope composition has been proved to be a robust tool to understand this process. Up till now, most zircons with age of $>$ 4.0 Ga have been found in the Yilgarn Craton of Western Australia [1-4]. The oldest zircon in the Eurasia is a detrital grain with SHRIMP U-Pb age of $4.1 \mathrm{Ga}$ in quartz schist from Pulan County in Tibet, although depositional time retains unknown [5]. A 4.1 Ga xenocrystal zircon from Ordovician volcanic rocks was found in western part of the North Qinling Orogenic Belt [6]. Detrital zircons and rocks as old as $3.8 \mathrm{Ga}$ were also reported using SHRIMP U-Pb dating in the Anshan area in North China [7,8]. The oldest zircon in South China is preserved in the sandstone from the Liantuo Formation in Yichang, Hubei Province, with a $\mathrm{U}-\mathrm{Pb}$ age of 3.8 and $4.0 \mathrm{Ga}$ for two-stage $\mathrm{Hf}$ model age [9]. Here, a detrital zircon with a U-Pb age of $4.1 \mathrm{Ga}$ in the Cambrian sandstone from the West Daming Mountain in

*Corresponding author (email: duyuansheng126@126.com)
Guangxi Province, South China, is reported. It is the oldest zircon in South China up to now.

\section{Location and description of sample}

Sample was collected from the West Daming Mountain in the western part of Nanning City, Guangxi Province, where tectonically belong to the Cathaysia Block, the South China Craton (Figure 1a, b). The exposed strata in the West Daming Mountain are the Lower Cambrian Xiaoneichong and Middle-Upper Cambrian Huangdongkou formations. Contact is conformable. The Xiaoneichong Formation is composed mainly of mid-thick pale-green quartz sandstone interbedding with mudstone, with the volume of mudstone increasing upwards. The Huangdongkou Formation consists mainly of pale-green quartz sandstone intercalated with mudstone. The succession is overlain unconformably by the Lower Devonian Lianhuashan Formation. Sample 11FS-3 from the Xiaoneichong Formation is a pale-green quartz sandstone with the angular, variable grain texture. It contains 


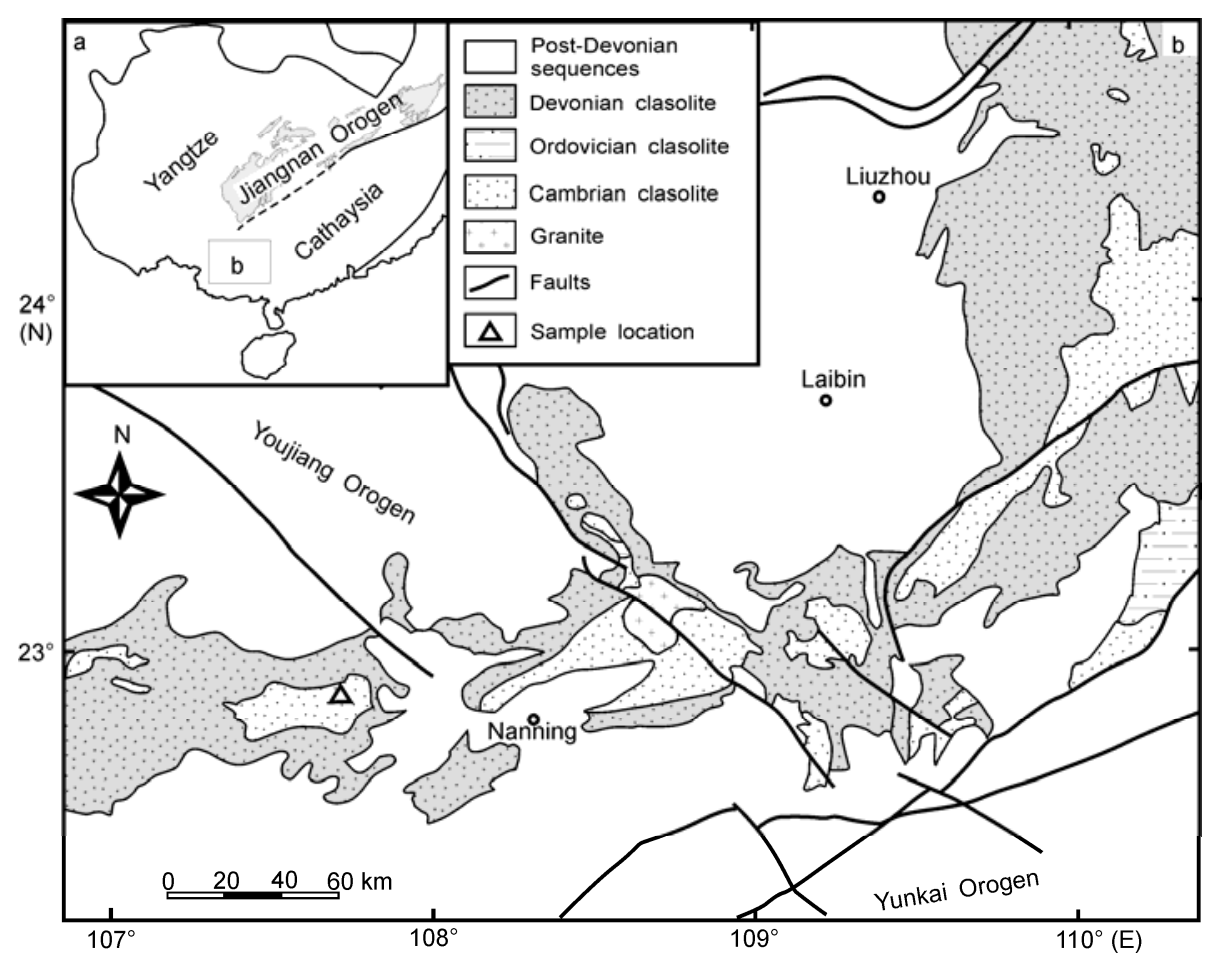

Figure 1 Outcrop distribution of strata and sampling location. Inset shows position of the study area.

$85.7 \%$ quartz, $5 \%$ feldspar and $9.3 \%$ lithic fragments.

\section{Analytical methods}

Zircons were separated by conventional heavy liquid and magnetic techniques. Grains were selected under a binocular microscope and mounted in epoxy resin, sectioned approximately in half, polished. All analyses in this study were conducted at the State Key Laboratory of Geological Processes and Mineral Resources, China University of Geosciences in Wuhan. Cathodoluminescence (CL) images, taken on a JXA-8100 with attached Gatan CL, were used to decipher the internal structures and origin of the sectioned grains and to guide $\mathrm{U}-\mathrm{Pb}$ dating and $\mathrm{Hf}$ isotope analysis. Zircon U-Pb dating was conducted by an Agilent 7500a laser inductively coupled plasma mass spectrometer (LA-ICP-MS). Laser sampling was performed using an excimer laser ablation system (GeoLas 2005). Detailed operating conditions follow the documents [10-12]. Zircon 91500 was used as external standard for age calculation and re-analyzed twice after every 5 analyses of the unknowns. Off-line selection and integration of background and analyte signals, and time-drift correction and quantitative calibration for trace element analyses and $\mathrm{U}-\mathrm{Pb}$ dating were performed by ICPMSDataCal [10,11]. Time-dependent drifts of $\mathrm{U}-\mathrm{Th}-\mathrm{Pb}$ isotopic ratios were corrected using a linear interpolation (with time) according to variations of the standard 91500 [11]. Preferred U-Th-Pb isotopic ratios used for 91500 are from the document [13]. Common $\mathrm{Pb}$ correc- tion was not performed as signal of measured ${ }^{204} \mathrm{~Pb}$ is low and $\mathrm{U}-\mathrm{Pb}$ ages are concordant or nearly concordant. Concordia diagrams and weighted mean calculations were made using Isoplot/Ex_ver3 [14].

Zircon Hf isotope analysis was carried out in situ using a Neptune MC-ICP-MS. The instrumental conditions and data acquisition were described by the documents [15]. The analyses were conducted with a beam diameter of $44 \mu \mathrm{m}$, a hit rate of $6 \mathrm{~Hz}$. Analytical spots were located close to or on the top of LA-ICP-MS spots or in the same growth domain as inferred from CL images. The ${ }^{176} \mathrm{Lu}$ and ${ }^{176} \mathrm{Yb}$ interferences on ${ }^{176} \mathrm{Hf}$ were subtracted using the signals of ${ }^{175} \mathrm{Lu}$ and ${ }^{173} \mathrm{Yb}$ and values of 0.02656 for ${ }^{176} \mathrm{Lu} /{ }^{175} \mathrm{Lu}$ [16] and 0.7876 for ${ }^{176} \mathrm{Yb} /{ }^{173} \mathrm{Yb}$ [17]. To monitor the accuracy of this correction, every 9 sample analyses were followed by analysis of 91500 and GJ-1 as reference zircons. During the analysis, the standard zircons gave $0.282303 \pm 8(n=15,1 \sigma)$ for 91500 with the recommended ${ }^{176} \mathrm{Hf} /{ }^{177} \mathrm{Hf}$ ratios of $0.282308 \pm 6[18]$ and $0.282009 \pm 6(n=15,1 \sigma)$ for GJ-1 with ${ }^{176} \mathrm{Hf} /{ }^{177} \mathrm{Hf}$ ratios of $0.282015 \pm 19$ [19], respectively. The decay constant for ${ }^{176} \mathrm{Lu}$ of $1.865 \times 10-11 \mathrm{a}-1$ was adopted [20]. $\varepsilon_{\mathrm{Hf}}(t)$ value was calculated relative to the chondritic reservoir with a ${ }^{176} \mathrm{Hf} /{ }^{177} \mathrm{Hf}$ ratio of 0.282772 and ${ }^{176} \mathrm{Lu} /$ ${ }^{177} \mathrm{Hf}$ of 0.0332 [16]. Single-stage Hf model ages $\left(T_{\mathrm{DM}}\right)$ were calculated by reference to depleted mantle with present-day ${ }^{176} \mathrm{Hf} /{ }^{177} \mathrm{Hf}$ ratio of 0.28325 and ${ }^{176} \mathrm{Lu} /{ }^{177} \mathrm{Hf}$ ratio of 0.0384 [21]. Two-stage Hf model ages $\left(T_{\mathrm{DM} 2}\right)$ were calculated by assuming a mean ${ }^{176} \mathrm{Hf} /{ }^{177} \mathrm{Hf}$ value of 0.015 for the average continental crust [22], except that Two-stage Hf model ages of zircon with the age of $4.1 \mathrm{Ga}$ was calculated 
by assuming a mean ${ }^{176} \mathrm{Hf} /{ }^{177} \mathrm{Hf}$ value of 0.022 for the average lower continental crust [23]. The model ages $\left(T_{\mathrm{DM}}\right)$ were taken for positive $\varepsilon_{\mathrm{Hf}}(t)$ values, and two-stage $\mathrm{Hf}$ model ages $\left(T_{\mathrm{DM} 2}\right)$ were taken for negative $\varepsilon_{\mathrm{Hf}}(t)$ values [24].

\section{Zircon origin, U-Pb ages and Hf isotopes}

Zircon grains are colorless to purple-red and most are subhedral crystals with prisms partially abraded. CL images show simple oscillatory zoning (Figure 2a, b, g, i), oscillatory zoned grain imposed with igneous sector zoning (Figure $2 \mathrm{~d}, \mathrm{e}$ ) and a core with oscillatory zoning enveloped by a metamorphic rim lacking internal structure (Figure 2c, f, h, j). Due to their narrow width of the metamorphic rim, zircons displaying multiple internal structures were analyzed in the core region. $\mathrm{Th} / \mathrm{U}$ ratios of grains range from 0.2 to 1.2 , consistent with a magmatic origin [25].

A total of 48 analyses were undertaken and zircon U-Pb isotopic compositions are presented in Table 1. Uncertainties on individual analyses in the data table and concordia plots are presented at $1 \sigma$. All analyses are shown on concordia plots (Figure 3); however, analyses that show greater than $10 \%$ discordance were not included in frequency diagrams (Figure 4), and ages less than $1000 \mathrm{Ma}$ are based on the ${ }^{206} \mathrm{~Pb} /{ }^{238} \mathrm{U}$ ratio whereas older ages are based on the ${ }^{206} \mathrm{~Pb} /{ }^{207} \mathrm{~Pb}$ ratio. The concordant ages demonstrate a wide span, ranging from $4107 \pm 29 \mathrm{Ma}$ to $513 \pm 8 \mathrm{Ma}$. Among them, 6 ages range from 2.8 to $2.3 \mathrm{Ga}$. The rest are grouped into age ranging from 1.8 to $0.5 \mathrm{Ga}$, with two prominent peaks of ages, namely, between 1.0 and $0.9 \mathrm{Ga}$, and between 1.3 $\mathrm{Ga}$ and $1.0 \mathrm{Ga}$, respectively. Scattered ages also occur at the two sides of peaks, including 11 grains from $1.7 \mathrm{Ga}$ to 1.3 $\mathrm{Ga}$ and 12 grains from $0.8 \mathrm{Ga}$ to $0.5 \mathrm{Ga}$ (Figure 4).

In-situ Lu-Hf isotope analyses were carried out on the zircon with the age of $4.1 \mathrm{Ga}$ and 25 grains with the ages ranging from 1.4 to $0.9 \mathrm{Ga}$. Zircon $\mathrm{Lu}-\mathrm{Hf}$ isotope composi- tions are listed in Table 2 and Figure 5. The single-stage and two-stage Hf model ages of zircon with U-Pb age of $4107 \pm 29 \mathrm{Ma}$ are $4102 \pm 42 \mathrm{Ma}$ and $4098 \pm 63 \mathrm{Ma}$, respectively. The $\varepsilon_{\mathrm{Hf}}(t)$ values of zircons with ages ranging from 1.4 to $0.9 \mathrm{Ga}$ are from -15.6 to +12.2 and their $\mathrm{Hf}$ model ages range from 2.9 to $1.1 \mathrm{Ga}$, suggesting that sources suffered the important episodes of juvenile crust growth and ancient crust reworking in the Mid-Neoproterozoic period.

\section{Discussion and conclusions}

The South China Craton consists of the Yangtze Block to the northwest and the Cathaysia Block to the southeast. The two blocks were amalgamated during the early Neoproterozoic along the Jiang-Shao suture zone associated with the formation of the Jiangnan orogen (Figure 1a). The previous studies document that the oldest zircon with a U-Pb age of $3.8 \mathrm{Ga}$ and model $\mathrm{Hf}$ ages of 3.96 to $4.00 \mathrm{Ga}$ is preserved in the sandstones from the Liantuo Formation in the Yangtze Gorge, suggesting presence of the Eoarchean crustal remnant in the Yangtze Block, with possible crustal growth as early as late Hadean [9]. A lot of detrital zircons with ages from 3.5 to $2.9 \mathrm{Ga}$ are reported in the Yangtze Block [9,26-31]. In addition, Gao et al. [32] and Jiao et al. [33] dated granitoid gneiss from the Kongling area as the oldest rock with $\mathrm{U}-\mathrm{Pb}$ age of 3.3-3.2 Ga in the Yangtze Block. The magmatic zircons in these rocks have two-stage $\mathrm{Hf}$ model ages of 3.7-3.4 Ga, indicating that the rocks were derived from partial melting of Eoarchean crust. These evidences from rocks and detrital sediments jointly suggest that the Eoarchean crust remnants are preserved in the Yangtze Block. The oldest rock in the Cathaysia Block is named as the Badu Group with an age range from 1.9 to $1.8 \mathrm{Ga}$ in southeastern Zhejiang and northwestern Fujian provinces [34-36], prominently younger than that in the Yangtze Block. However, the group contains the detrital zircon with


Figure 2 CL images of representative zircons from the Cambrian sandstone in West Daming Mountain, Guangxi, showing main types of internal structures within zircon grains. Solid circles denote U-Pb analysis spot and dashed circles denote Lu-Hf analysis spot. Spot numbers are denoted in brackets. 
Table 1 LA-ICP-MS detrital zircon U-Pb isotope data for the Cambrian sandstone (11FS-3) in West Daming Mountain, Guangxi ${ }^{\text {a) }}$

\begin{tabular}{|c|c|c|c|c|c|c|c|c|c|c|c|c|c|}
\hline \multirow{2}{*}{ Spot } & \multicolumn{2}{|c|}{${ }^{207} \mathrm{~Pb} /{ }^{206} \mathrm{~Pb}$} & \multicolumn{2}{|c|}{${ }^{207} \mathrm{~Pb} /{ }^{235} \mathrm{U}$} & \multicolumn{2}{|c|}{${ }^{206} \mathrm{~Pb} /{ }^{238} \mathrm{U}$} & \multicolumn{2}{|c|}{${ }^{207} \mathrm{~Pb} /{ }^{206} \mathrm{~Pb}$} & \multicolumn{2}{|c|}{${ }^{207} \mathrm{~Pb} /{ }^{235} \mathrm{U}$} & \multicolumn{2}{|c|}{${ }^{206} \mathrm{~Pb} /{ }^{238} \mathrm{U}$} & \multirow{2}{*}{$\begin{array}{c}\text { Concordance } \\
(\%) \\
\end{array}$} \\
\hline & Ratio & $1 \sigma$ & Ratio & $1 \sigma$ & Ratio & $1 \sigma$ & Age (Ma) & $1 \sigma$ & Age (Ma) & $1 \sigma$ & Age (Ma) & $1 \sigma$ & \\
\hline 1.1 & 0.0759 & 0.0019 & 2.0084 & 0.0481 & 0.1899 & 0.0019 & 1092 & 50 & 1118 & 16 & 1121 & 10 & 99 \\
\hline 1.2 & 0.0663 & 0.0013 & 0.9223 & 0.0185 & 0.0994 & 0.0009 & 817 & 42 & 664 & 10 & 611 & 5 & 91 \\
\hline 1.3 & 0.0747 & 0.0020 & 1.9769 & 0.0540 & 0.1895 & 0.0023 & 1061 & 54 & 1108 & 18 & 1119 & 12 & 98 \\
\hline 1.4 & 0.1607 & 0.0032 & 10.6352 & 0.2158 & 0.4729 & 0.0049 & 2463 & 35 & 2492 & 19 & 2496 & 22 & 99 \\
\hline 2.1 & 0.1649 & 0.0039 & 10.9253 & 0.2532 & 0.4748 & 0.0061 & 2506 & 40 & 2517 & 22 & 2505 & 26 & 99 \\
\hline 2.2 & 0.0862 & 0.0027 & 2.6115 & 0.0743 & 0.2175 & 0.0028 & 1343 & 60 & 1304 & 21 & 1269 & 15 & 97 \\
\hline 2.3 & 0.0796 & 0.0034 & 1.9666 & 0.0825 & 0.1827 & 0.0061 & 1187 & 87 & 1104 & 28 & 1082 & 33 & 97 \\
\hline 2.4 & 0.2028 & 0.0052 & 13.9780 & 0.3518 & 0.4963 & 0.0075 & 2849 & 41 & 2748 & 24 & 2598 & 32 & 94 \\
\hline 2.5 & 0.0738 & 0.0017 & 1.6797 & 0.0373 & 0.1630 & 0.0016 & 1039 & 46 & 1001 & 14 & 974 & 9 & 97 \\
\hline 3.1 & 0.0641 & 0.0022 & 0.8565 & 0.0307 & 0.0959 & 0.0013 & 746 & 42 & 628 & 17 & 590 & 7 & 93 \\
\hline 3.2 & 0.0763 & 0.0027 & 1.6147 & 0.0569 & 0.1520 & 0.0019 & 1103 & 70 & 976 & 22 & 912 & 11 & 93 \\
\hline 3.3 & 0.0634 & 0.0037 & 0.7313 & 0.0442 & 0.0828 & 0.0014 & 720 & 126 & 557 & 26 & 513 & 8 & 91 \\
\hline 3.4 & 0.0810 & 0.0022 & 1.7761 & 0.0555 & 0.1568 & 0.0023 & 1220 & 53 & 1037 & 20 & 939 & 13 & 90 \\
\hline 3.5 & 0.0755 & 0.0021 & 1.6573 & 0.0447 & 0.1578 & 0.0017 & 1081 & 60 & 992 & 17 & 945 & 9 & 95 \\
\hline 4.1 & 0.1495 & 0.0037 & 8.1968 & 0.2140 & 0.3954 & 0.0070 & 2340 & 44 & 2253 & 24 & 2148 & 32 & 95 \\
\hline 4.2 & 0.4565 & 0.0090 & 57.2462 & 1.1536 & 0.8964 & 0.0088 & 4107 & 29 & 4127 & 20 & 4125 & 30 & 99 \\
\hline 5.1 & 0.0978 & 0.0038 & 3.0161 & 0.1195 & 0.2212 & 0.0036 & 1583 & 72 & 1412 & 30 & 1288 & 19 & 90 \\
\hline 5.2 & 0.0664 & 0.0022 & 1.1746 & 0.0381 & 0.1267 & 0.0016 & 820 & 69 & 789 & 18 & 769 & 9 & 97 \\
\hline 5.3 & 0.0705 & 0.0028 & 1.3081 & 0.0494 & 0.1340 & 0.0019 & 944 & 86 & 849 & 22 & 811 & 11 & 95 \\
\hline 5.4 & 0.1076 & 0.0098 & 2.0640 & 0.1897 & 0.1489 & 0.0068 & 1761 & 167 & 1137 & 63 & 895 & 38 & 76 \\
\hline 5.5 & 0.0745 & 0.0037 & 1.8386 & 0.0935 & 0.1781 & 0.0024 & 1055 & 100 & 1059 & 33 & 1057 & 13 & 99 \\
\hline 6.1 & 0.1039 & 0.0022 & 4.1554 & 0.0817 & 0.2883 & 0.0032 & 1696 & 71 & 1665 & 16 & 1633 & 16 & 98 \\
\hline 6.2 & 0.0796 & 0.0023 & 2.4859 & 0.0714 & 0.2251 & 0.0026 & 1187 & 57 & 1268 & 21 & 1309 & 14 & 96 \\
\hline 6.3 & 0.0770 & 0.0021 & 2.0237 & 0.0542 & 0.1899 & 0.0024 & 1122 & 21 & 1124 & 18 & 1121 & 13 & 99 \\
\hline 6.4 & 0.0688 & 0.0019 & 1.0386 & 0.0321 & 0.1094 & 0.0022 & 900 & 56 & 723 & 16 & 669 & 13 & 92 \\
\hline 7.1 & 0.1084 & 0.0025 & 5.2190 & 0.1210 & 0.3480 & 0.0040 & 1773 & 43 & 1856 & 20 & 1925 & 19 & 96 \\
\hline 7.2 & 0.1050 & 0.0020 & 4.8056 & 0.0958 & 0.3297 & 0.0028 & 1714 & 36 & 1786 & 17 & 1837 & 13 & 97 \\
\hline 7.3 & 0.0884 & 0.0040 & 2.5068 & 0.1298 & 0.2059 & 0.0057 & 1392 & 87 & 1274 & 38 & 1207 & 30 & 94 \\
\hline 7.4 & 0.0678 & 0.0026 & 1.4095 & 0.0516 & 0.1528 & 0.0031 & 865 & 79 & 893 & 22 & 917 & 17 & 97 \\
\hline 8.1 & 0.1735 & 0.0037 & 10.6187 & 0.2769 & 0.4395 & 0.0064 & 2592 & 36 & 2490 & 24 & 2348 & 29 & 94 \\
\hline 8.2 & 0.0682 & 0.0018 & 1.5076 & 0.0394 & 0.1593 & 0.0016 & 876 & 54 & 933 & 16 & 953 & 9 & 97 \\
\hline 8.3 & 0.0721 & 0.0018 & 1.6092 & 0.0400 & 0.1604 & 0.0015 & 989 & 50 & 974 & 16 & 959 & 8 & 98 \\
\hline 8.4 & 0.0921 & 0.0022 & 3.3578 & 0.0803 & 0.2625 & 0.0026 & 1469 & 41 & 1495 & 19 & 1502 & 13 & 99 \\
\hline 9.1 & 0.1039 & 0.0025 & 4.2664 & 0.1005 & 0.2955 & 0.0030 & 1695 & 45 & 1687 & 19 & 1669 & 15 & 98 \\
\hline 9.2 & 0.0747 & 0.0026 & 1.8324 & 0.0599 & 0.1774 & 0.0021 & 1061 & 69 & 1057 & 21 & 1053 & 12 & 99 \\
\hline 9.3 & 0.0612 & 0.0029 & 0.7362 & 0.0328 & 0.0867 & 0.0012 & 656 & 102 & 560 & 19 & 536 & 7 & 95 \\
\hline 10.1 & 0.0883 & 0.0025 & 2.3710 & 0.0643 & 0.1926 & 0.0019 & 1391 & 21 & 1234 & 19 & 1136 & 10 & 91 \\
\hline 10.2 & 0.0699 & 0.0025 & 1.3017 & 0.0473 & 0.1343 & 0.0019 & 924 & 73 & 846 & 21 & 813 & 11 & 95 \\
\hline 10.3 & 0.0819 & 0.0019 & 2.2055 & 0.0537 & 0.1935 & 0.0026 & 1244 & 45 & 1183 & 17 & 1140 & 14 & 96 \\
\hline 11.1 & 0.0706 & 0.0015 & 1.2603 & 0.0301 & 0.1278 & 0.0016 & 946 & 44 & 828 & 14 & 775 & 9 & 93 \\
\hline 11.2 & 0.0819 & 0.0028 & 2.1589 & 0.0700 & 0.1920 & 0.0033 & 1244 & 67 & 1168 & 23 & 1132 & 18 & 96 \\
\hline 11.3 & 0.0910 & 0.0024 & 3.0357 & 0.0900 & 0.2390 & 0.0038 & 1456 & 50 & 1417 & 23 & 1381 & 20 & 97 \\
\hline 15.2 & 0.0701 & 0.0039 & 1.3568 & 0.0725 & 0.1407 & 0.0027 & 931 & 115 & 871 & 31 & 849 & 15 & 97 \\
\hline 15.3 & 0.1923 & 0.0049 & 14.0008 & 0.3631 & 0.5175 & 0.0066 & 2762 & 42 & 2750 & 25 & 2688 & 28 & 97 \\
\hline 16.1 & 0.0706 & 0.0018 & 1.4129 & 0.0366 & 0.1432 & 0.0023 & 946 & 53 & 894 & 15 & 863 & 13 & 96 \\
\hline 16.2 & 0.0759 & 0.0019 & 1.9289 & 0.0465 & 0.1817 & 0.0022 & 1092 & 50 & 1091 & 16 & 1076 & 12 & 98 \\
\hline 16.3 & 0.0871 & 0.0024 & 2.2561 & 0.0629 & 0.1865 & 0.0031 & 1365 & 54 & 1199 & 20 & 1102 & 17 & 91 \\
\hline 16.4 & 0.0786 & 0.0021 & 2.0346 & 0.0542 & 0.1850 & 0.0022 & 1165 & 53 & 1127 & 18 & 1094 & 12 & 97 \\
\hline
\end{tabular}




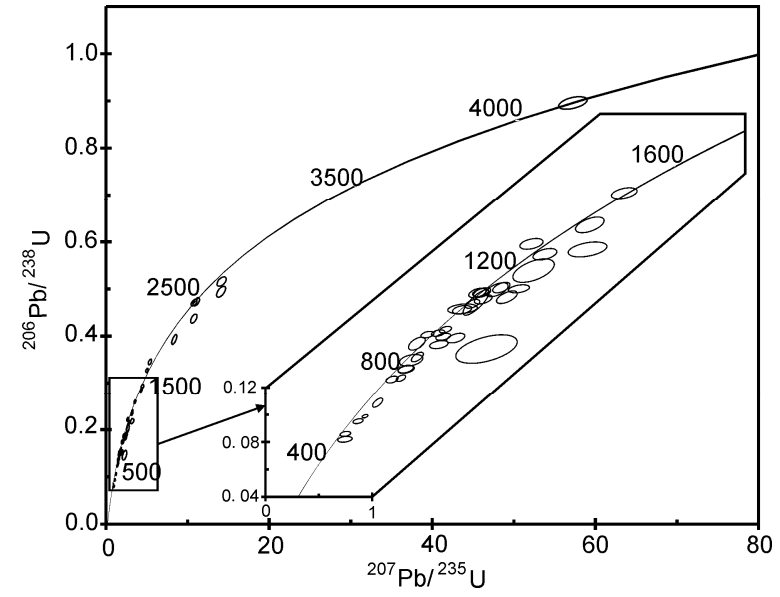

Figure $3 \mathrm{U}-\mathrm{Pb}$ concordia diagram of detrital zircon from the Cambrian sandstone in West Daming Mountain, Guangxi Province.

$\mathrm{U}-\mathrm{Pb}$ age of 3.6 Ga and $\mathrm{Hf}$ model age of 3.99 Ga [35], Integrated with $\mathrm{Yu}$ et al's finding of a detrital zircon with $\mathrm{U}-\mathrm{Pb}$ age of $3.7 \mathrm{Ga}$ and $\mathrm{Hf}$ model age of $4.07 \mathrm{Ga}$ in the Tanxi gneiss at Nanxiong, northern Guangdong Province [37], indicating the existence of Eoarchean crustal remnants and continental growth episode in the late Hadean in the Cathaysia Block. Eoarchean ages frequently found in the

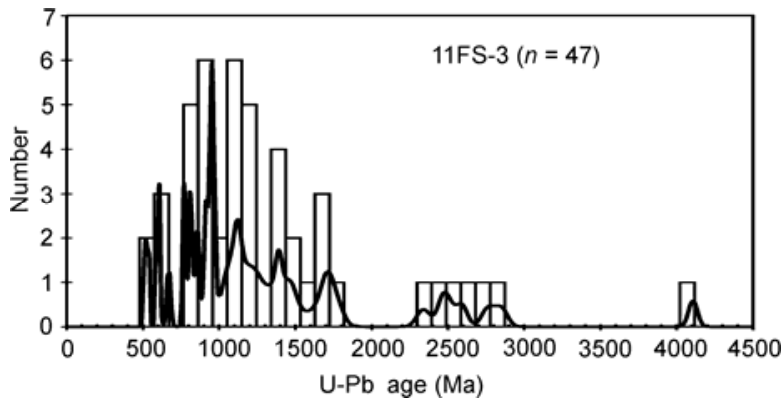

Figure 4 Relative probability density diagram of ages with concordance between $90 \%$ and $110 \%$ for the analyzed zircons from the Cambrian sandstone in West Daming Mountain, Guangxi.

Yangtze and Cathaysia blocks indicate that Eoarchean crustal remnants are widespread in South China. Hf isotope analyses for some of the Eoarchean zircons indicate the presence of Hadean crustal remnants in South China, which is confirmed by the detrital zircon with the Hadean age in this publication.

The Hadean zircons are located in the core of grains with a core-mantle-rim structure (Figure $2 \mathrm{f}$ ). U-Pb dating was conducted on the core region and yielded $\mathrm{a}{ }^{207} \mathrm{~Pb} /{ }^{206} \mathrm{~Pb}$ age of $4107 \pm 29 \mathrm{Ma}$. The core displays oscillatory zoning, combing with a $\mathrm{Th} / \mathrm{U}$ ratio of 1.09 , indicating a magmatic

Table 2 Hf isotope data of detrital zircon in the Cambrian sandstone (11FS-3) in West Daming Mountain, Guangxi ${ }^{\text {a) }}$

\begin{tabular}{|c|c|c|c|c|c|c|c|c|c|c|c|c|}
\hline Spot & ${ }^{176} \mathrm{Hf}^{\prime 177} \mathrm{Hf}$ & $1 \sigma$ & ${ }^{176} \mathrm{Lu} /{ }^{177} \mathrm{Hf}$ & $1 \sigma$ & ${ }^{176} \mathrm{Yb} /{ }^{177} \mathrm{Hf}$ & $1 \sigma$ & Age (Ma) & $\varepsilon_{\mathrm{Hf}}(t)$ & $T_{\mathrm{DM}}(\mathrm{Ma})$ & $\pm(1 \sigma)$ & $T_{\mathrm{DM} 2}(\mathrm{Ma})$ & $\pm(1 \sigma)$ \\
\hline 1.1 & 0.282163 & 0.000009 & 0.000809 & 0.000006 & 0.032647 & 0.000330 & 1092 & 2.0 & 1528 & 13 & 1789 & 21 \\
\hline 1.3 & 0.282238 & 0.000011 & 0.000854 & 0.000010 & 0.036587 & 0.000357 & 1061 & 4.0 & 1426 & 15 & 1643 & 24 \\
\hline 2.3 & 0.282163 & 0.000008 & 0.000542 & 0.000015 & 0.023803 & 0.000761 & 1187 & 4.3 & 1518 & 11 & 1720 & 17 \\
\hline 2.2 & 0.282000 & 0.000011 & 0.000557 & 0.000014 & 0.022077 & 0.000470 & 1343 & 2.0 & 1743 & 15 & 1987 & 24 \\
\hline 2.5 & 0.282248 & 0.000008 & 0.000634 & 0.000007 & 0.027468 & 0.000279 & 974 & 2.6 & 1405 & 11 & 1666 & 17 \\
\hline 3.4 & 0.282177 & 0.000016 & 0.000546 & 0.000012 & 0.027575 & 0.000601 & 939 & -0.6 & 1499 & 22 & 1841 & 35 \\
\hline 3.2 & 0.282260 & 0.000012 & 0.001319 & 0.000033 & 0.049800 & 0.001178 & 912 & 1.2 & 1412 & 18 & 1701 & 28 \\
\hline 3.5 & 0.282286 & 0.000011 & 0.001289 & 0.000024 & 0.050757 & 0.001046 & 945 & 2.9 & 1375 & 16 & 1624 & 26 \\
\hline 4.2 & 0.280407 & 0.000015 & 0.002640 & 0.000054 & 0.118508 & 0.002543 & 4107 & 2.4 & 4102 & 21 & 4098 & 32 \\
\hline 5.5 & 0.282427 & 0.000008 & 0.000492 & 0.000002 & 0.016080 & 0.000094 & 1055 & 10.8 & 1152 & 12 & 1211 & 19 \\
\hline 6.4 & 0.282221 & 0.000010 & 0.000784 & 0.000036 & 0.035481 & 0.001541 & 669 & -5.1 & 1447 & 14 & 1915 & 23 \\
\hline 6.2 & 0.281992 & 0.000010 & 0.000307 & 0.000003 & 0.009499 & 0.000186 & 1187 & -1.5 & 1742 & 14 & 2087 & 23 \\
\hline 7.3 & 0.282237 & 0.000013 & 0.001448 & 0.000026 & 0.059613 & 0.000615 & 1392 & 10.7 & 1450 & 18 & 1483 & 28 \\
\hline 7.4 & 0.281792 & 0.000013 & 0.001944 & 0.000077 & 0.066143 & 0.002541 & 917 & -15.6 & 2103 & 19 & 2756 & 29 \\
\hline 8.3 & 0.282262 & 0.000013 & 0.001526 & 0.000070 & 0.064658 & 0.002612 & 959 & 2.2 & 1418 & 18 & 1679 & 29 \\
\hline 8.4 & 0.281567 & 0.000009 & 0.001318 & 0.000011 & 0.054846 & 0.000433 & 1469 & -11.3 & 2380 & 13 & 2907 & 20 \\
\hline 8.2 & 0.282167 & 0.000008 & 0.000730 & 0.000002 & 0.027580 & 0.000163 & 953 & -0.8 & 1520 & 12 & 1861 & 19 \\
\hline 9.2 & 0.281891 & 0.000010 & 0.000588 & 0.000030 & 0.026017 & 0.001416 & 1061 & -8.1 & 1893 & 13 & 2400 & 22 \\
\hline 10.1 & 0.282052 & 0.000007 & 0.000204 & 0.000003 & 0.009285 & 0.000078 & 1391 & 5.2 & 1656 & 10 & 1821 & 16 \\
\hline 10.3 & 0.282003 & 0.000009 & 0.001262 & 0.000012 & 0.046304 & 0.000568 & 1244 & -0.7 & 1771 & 13 & 2077 & 21 \\
\hline 11.2 & 0.282085 & 0.000011 & 0.000568 & 0.000021 & 0.023419 & 0.001075 & 1244 & 2.8 & 1626 & 15 & 1859 & 24 \\
\hline 11.3 & 0.281716 & 0.000009 & 0.001863 & 0.000030 & 0.070643 & 0.001430 & 1456 & -6.9 & 2205 & 13 & 2621 & 20 \\
\hline 16.2 & 0.281973 & 0.000010 & 0.000802 & 0.000003 & 0.033298 & 0.000152 & 1092 & -4.7 & 1791 & 14 & 2210 & 22 \\
\hline 16.3 & 0.282309 & 0.000022 & 0.001889 & 0.000071 & 0.071707 & 0.002666 & 1365 & 12.2 & 1365 & 32 & 1365 & 49 \\
\hline 16.4 & 0.282036 & 0.000008 & 0.000722 & 0.000010 & 0.027886 & 0.000529 & 1165 & -0.8 & 1700 & 11 & 2023 & 17 \\
\hline
\end{tabular}

a) Spots are consistent with those in Table 1. 


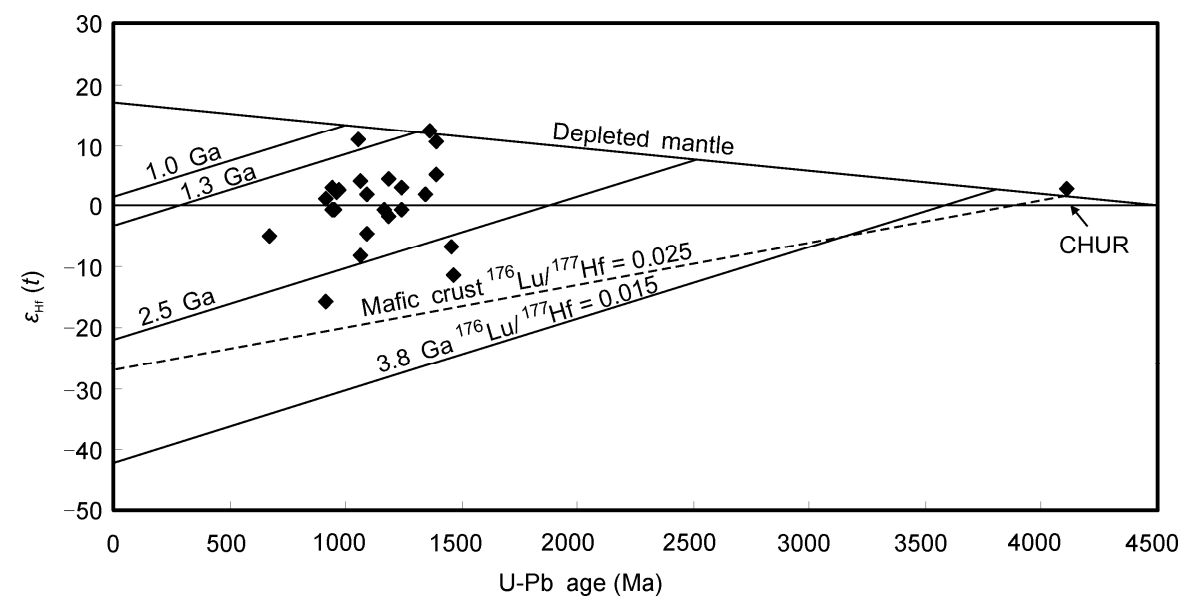

Figure 5 Relationship between $\varepsilon_{\mathrm{Hf}}(t)$ and U-Pb ages for zircons from the Cambrian sandstone in West Daming Mountain, Guangxi.

origin. Hf isotope analysis was conducted on the top and slightly upper left of U-Pb dating spot (Figure $2 \mathrm{f}$ ). ${ }^{176} \mathrm{Hf} /$ ${ }^{177} \mathrm{Hf}$ ratios did not change significantly in the 50s data acquisition, which suggests that zircon on the ablation spot has homogeneous Hf isotope composition and is derived from uniform magma. Hf isotope analysis gave highly positive $\varepsilon_{\mathrm{Hf}}(t)$ values of +2.4 , consistent with the value of homochronous depleted mantle within the uncertainty (Figure 5). Single-stage and two-stage model ages are $4102 \pm 42 \mathrm{Ma}$ and $4098 \pm 63 \mathrm{Ma}$, respectively. Two-stage Hf model ages of Hadean zircon was calculated by assuming a mean ${ }^{176} \mathrm{Hf} /$ ${ }^{177} \mathrm{Hf}$ value of 0.022 [23] for the average lower continental crust on the basis of Kemp et al's inference that composition of Hadean crust was mafic and similar to that of the lower continental crust [4]. The good agreement between zircon $\mathrm{U}-\mathrm{Pb}$ and $\mathrm{Hf}$ model ages clearly points out the growth and immediate reworking of juvenile crust from the depleted mantle by the ca. 4.1 Ma magmatism, which indicates the existence of depleted mantle and crustal growth at ca. $4.1 \mathrm{Ga}$.

Vermeesch [38] argued that, within 95\% confidence, no fraction $\geqslant 0.05$ of the population was missed, and the optimal number of grains that should be dated of a detrital provenance sample is 117 . But once these fractions have been found by fewer than 117 grains to be dated, it is enough to prove the presence of one or more specific age fractions in a detrital population. Although only 48 zircons were dated in this study, six grains and eighteen grains yielded "Pan-Africa" (0.6-0.5 Ga) and Grenville (1.3-0.9 $\mathrm{Ga}$ ) ages (Figure 4), respectively, they differ from the tectonic events of South China, and are consistent with those of Gondwana supercontinent. A number of exotic zircons with "Pan-Africa" and Grenville ages are preserved in the underlying Neoproterozoic strata in the southern part of South China [39-42]. However, available geological evidences in South China - that sag phase prevailed during the late Neoproterozoic period [43], and that the Neoproterozoic strata contacted conformably with the lower Paleozoic strata - suggest that no orogeny happened during the Cambrian. It is impossible that zircons with "Pan-Africa" and Grenville ages derived from the recycling sediments. They must have come from an exotic continent related to Gondwana supercontinent during the Cambrian period, which indicates a connection between South China and Gondwana in the Cambrian period. The southern part of South China may have more complex histories of crustal growth and tectonic evolution than ever known, which needs further study.

This work was supported by the National Natural Science Foundation of China (40972078 and 40921062), "111" Project (B08030) and the Fundamental Research Funds for the Central Universities, China University of Geosciences (Wuhan). We thank Prof. Liu Yongsheng and Hu Zhaochu for their help with zircon $\mathrm{U}-\mathrm{Pb}$ dating and $\mathrm{Hf}$ isotope analyses. We also thank Prof. Wu Yuanbao and Ling Wenli for their helpful comments on the manuscript. Two anonymous reviewers are thanked for their constructive and valuable comments.

1 Wilde S A, Valley J W, Peck W H, et al. Evidence from detrital zircons for the existence of continental crust and oceans on the Earth 4.4 Ga ago. Nature, 2001, 409: 175-178

2 Harrison T M, Blichert-Toft J, Muller W, et al. Heterogeneous Hadean Hafnium: Evidence for continental crust at 4.4 to $4.5 \mathrm{Ga}$. Science, 2005, 310: 1947

3 Harrison T M, Schmitt A K, McCulloch M T, et al. Early (4.5 Ga) formation of terrestrial crust: $\mathrm{Lu}-\mathrm{Hf}, \delta^{18} \mathrm{O}$, and Ti thermometry results for Hadean zircons. Earth Planet Sci Lett, 2008, 268: 476-486

4 Kemp A I S, Wilde S A, Hawkesworth C J, et al. Hadean crustal evolution revisited: New constraints from $\mathrm{Pb}-\mathrm{Hf}$ isotope systematics of the Jack Hills zircons. Earth Planet Sci Lett, 2010, 296: 45-56

5 Duo J, Wen C Q, Guo J C, et al. 4.1 Ga old detrital zircon in western Tibet of China. Chin Sci Bull, 2007, 52: 19-22

6 Wang H L, Chen L, Sun Y, et al. 4.1 Ga xenocrystal zircon from Ordovician volcanic rocks in western part of the North Qinling Orogenic Belt. Chin Sci Bull, 2007, 52: 1685-1693

7 Liu D Y, Nutman A P, Compston W, et al. Remnants of 3800 Ma crust in Chinese part of Sino-Korean craton. Geology, 1992, 20: 339342

8 Wan Y S, Liu D Y, Song B, et al. Geochemical and Nd isotopic compositions of 3.8 Ga meta-quartz dioritic and trondhjemitic rocks from the Anshan area and their geological significance. J Asian Earth Sci, 2005, 24: 563-575 
9 Zhang $\mathrm{S} \mathrm{B}$, Zheng Y F, Wu Y B, et al. Zircon U-Pb age and $\mathrm{Hf}$ isotope evidence for $3.8 \mathrm{Ga}$ crustal remnant and episodic rework-ing of Archean crust in South China. Earth Planet Sci Lett, 2006, 252: 56-71

10 Liu Y S, Hu Z C, Gao S, et al. In situ analysis of major and trace elements of anhydrous minerals by LA-ICP-MS without applying an internal standard. Chem Geol, 2008, 257: 34-43

11 Liu Y, Gao S, Hu Z, et al. Continental and oceanic crust recycling-induced melt-peridotite interactions in the Trans-North China Orogen: $\mathrm{U}-\mathrm{Pb}$ dating, $\mathrm{Hf}$ isotopes and trace elements in zircons of mantle xenoliths. J Petrol, 2010, 51: 537-571

12 Liu Y, Hu Z, Zong K, et al. Reappraisement and refinement of zircon $\mathrm{U}-\mathrm{Pb}$ isotope and trace element analyses by LA-ICP-MS. Chin Sci Bull, 2010, 55: 1535-1546

13 Wiedenbeck M, Alle P, Corfu F, et al. Three natural zircon standards for U-Th- $\mathrm{Pb}$, Lu-Hf, trace element and REE analyses. Geostand Geoanal Res, 1995, 19: 1-23

14 Ludwig K R. Users manual for Isoplot/Ex (rev 2.49): A geochronological toolkit for Microsoft Excel. Berkeley Geochron Cent Spec Publ, 2001. 1-55

15 Hu Z C, Liu Y S, Gao S, et al. Improved in situ Hf isotope ratio analysis of zircon using newly designed $\mathrm{X}$ skimmer cone and jet sample cone in combination with the addition of nitrogen by laser ablation multiple collector ICP-MS. J Anal At Spect, 2012, doi: 10.1039/C2JA30078H

16 Blichert-Toft J, Albarede F. The Lu-Hf geochemistry of chondrites and the evolution of the mantle-crust system. Earth Planet Sci Lett, 1997, 148: 243-258

17 McCulloch M T, Rosman K J R, De Laeter J R. The isotopic and elemental abundance of ytterbium in meteorites and terrestrial samples. Geochim Cosmochim Acta, 1977, 41: 1703-1707

18 Blichert-Toft $\mathrm{J}$. The Hf isotopic composition of zircon reference material 91500. Chem Geol, 2008, 253: 252-257

19 Elhlou S, Belousova E, Griffin W L, et al. Trace element and isotopic composition of GJ-red zircon standard by laser ablation. Geochim Cosmochim Acta, 2006, 70: A158

20 Scherer E, Munker C, Mezger K. Calibration of the lutetium-hafnium clock. Science, 2001, 293: 683-687

21 Vervoort J D, Blichert-Toft J. Evolution of the depleted mantle: Hf isotope evidence from juvenile rocks through time. Geochim Cosmochim Acta, 1999, 63: 533-556

22 Griffin W L, Wang X, Jackson S E, et al. Zircon chemistry and magma mixing, SE China: In-situ analysis of Hf isotopes, Tonglu and Pingtan igneous complexes. Lithos, 2002, 61: 237-269

23 Amelin Y, Lee D C, Halliday A N, et al. Nature of the Earth's earliest crust from hafnium isotopes in single detrital zircons. Nature, 1999, 399: 252-255

24 Zheng Y F, Zhao Z F, Wu Y B, et al. Zircon U-Pb age, Hf and $\mathrm{O}$ isotope constraints on protolith origin of ultrahigh-pressure eclogite and gneiss in the Dabie orogen. Chem Geol, 2006, 231: 135-158

$25 \mathrm{Wu}$ Y B, Zheng Y F. Genesis of zircon and its constraints on interpretation of U-Pb age. Chin Sci Bull, 2004, 49: 1554-1569

26 Qiu Y M, Gao S, McNaughton N J, et al. First evidence of $\geqslant 3.2 \mathrm{Ga}$ continental crust in the Yangtze craton of south China and its implications for Archean crustal evolution and Phanerozoic tectonics.
Geology, 2000, 28: 11-14

27 Zheng J P, Griffin W L, O'Reilly S Y, et al. Widespread Archean basement beneath the Yangtze craton. Geology, 2006, 34: 417-420

28 Zhang S B, Zheng Y F, Wu Y B, et al. Zircon U-Pb age and Hf-O isotope evidence for Paleoproterozoic metamorphic event in South China. Precambrain Res, 2006, 151: 265-288

29 Zhang S B, Zheng Y F, Wu Y B, et al. Zircon isotope evidence for $\geqslant 3.5 \mathrm{Ga}$ continental crust in the Yangtze craton of China. Precambrian Res, 2006, 146: 16-34

30 Zheng Y F, Zhang S B. Formation and evolution of Precambrian continental crust in South China. Chin Sci Bull, 2007, 52: 1-12

31 Liu X M, Gao S, Diwu C R, et al. Precambrian crustal growth of the Yangtze Craton as revealed by detrital zircon. Amer J Sci, 2008, 308: 421-468

32 Gao S, Yang J, Zhou L, et al. Age and growth of the Archean Kongling terrain, South China, with emphasis on 3.3 Ga granitoid gneisses. Amer J Sci, 2011, 311: 153-182

33 Jiao W F, Wu Y B, Peng M, et al. The oldest basement rock in the Yangtze Craton revealed by zircon U-Pb age and Hf isotope composition. Sci China Ser D-Earth Sci, 2009, 52: 1393-1399

$34 \mathrm{Yu} \mathrm{J} \mathrm{H,} \mathrm{Wang} \mathrm{L} \mathrm{J,} \mathrm{Griffin} \mathrm{W} \mathrm{L,} \mathrm{et} \mathrm{al.} \mathrm{A} \mathrm{Paleoproterozoic} \mathrm{orogeny}$ recorded in a long-lived cratonic remnant (Wuyishan terrane), eastern Cathaysia Block, China. Precambrian Res, 2009, 174: 347-363

35 Yu J H, O'Reilly S Y, Zhou M F, et al. U-Pb geochronology and Hf-Nd isotopic geochemistry of the Badu Complex, Southeastern China: Implications for the Precambrian crustal evolution and paleogeography of the Cathaysia Block. Precambrian Res, 2011, doi: 10.1016/j.precamres

36 Liu R, Zhou H W, Zhang L, et al. Paleoproterozoic reworking of ancient crust in the Cathaysia Block, South China: Evidence from zircon trace elements, U-Pb and Lu-Hf isotopes. Chin Sci Bull, 2009, 54: 1543-1554

37 Yu J H, O'Reilly Y S, Wang L J, et al. Finding of ancient materials in Cathaysia and implication for the formation of Precambrian crust. Chin Sci Bull, 2007, 52: 13-22

38 Vermeesch P. How many grains are needed for a provenance study? Earth Planet Sci Lett, 2004, 224: 441-451

39 Yu J H, O'Reilly S Y, Wang L J, et al. Where was South China in the Rodinia supercontinent? Evidence from U-Pb geochronology and $\mathrm{Hf}$ isotopes of detrital zircons. Precambrain Res, 2008, 164: 1-15

40 Wang L J, Yu J H, O'Reilly S Y, et al. Grenvillian orogeny in the Southern Cathaysia Block: Constraints from $\mathrm{U}-\mathrm{Pb}$ ages and $\mathrm{Lu}-\mathrm{Hf}$ isotopes in zircon from metamorphic basement. Chin Sci Bull, 2008, 53: 3037-3050

41 Wang Y J, Zhang F F, Fan W M, et al. Tectonic setting of the South China Block in the early Paleozoic: Resolving intracontinental and ocean closure models from detrital zircon $\mathrm{U}-\mathrm{Pb}$ geochronology. Tectonics, 2010, 29, doi: 10.1029/2010TC002750

42 Xiang L, Shu L S. Pre-Devonian tectonic evolution of the eastern South China Block: Geochronological evidence from detrital zircons. Sci China Ser D-Earth Sci, 2010, 53: 1427-1444

43 Wang J, Li Z X. History of Neoproterozoic rift basins in South China: Implications for Rodinia break-up. Precambrain Res, 2003, 122: $141-158$

Open Access This article is distributed under the terms of the Creative Commons Attribution License which permits any use, distribution, and reproduction in any medium, provided the original author(s) and source are credited. 